\title{
STUDI DESKRIPTIF KINERJA DOSEN DALAM PROSES PEMBELAJARAN DI UNIVERSITAS MUHAMMADIYAH SURAKARTA
}

\author{
Abdullah Aly \\ Dosen pada Prodi Pendidikan Agama Islam (S1 \& S2), Fakultas Agama Islam, \\ Universitas Muhammadiyah Surakarta \\ E-Mail: aa130@ums.ac.id
}

\begin{abstract}
Entering the age of 56, UMS still need to make improvements and development in the learning process. For the sake of improvement and development, this study was conducted in order to map the performance of UMS lecturer in lesson plan, in the implementation of learning and in the evaluation of learning outcomes. Based on non-experimental descriptive study of the survey form, by questionnaire, review of documents, and FGD, the study found three important findings. First, UMS lecturer has a good performance in lesson planning. Second, UMS lecturer's performance in the implementation of the learning process has not been entirely good, because they are not using a variety of learning methods. Third, UMS lecturer's performance in the evaluation of learning outcomes is quite good. By the three findings above can be said that the performance of UMS lecturer in the learning process nearly meet the liability component required by Law on Teachers and Lecturers in 2005 and has been referred to the PP 19 on National Education Standards (NES) in 2005.
\end{abstract}

Keywords: Lecturer's Performance; Law on Teachers and Lecturers; the National Standards; Student Centered Learning (SCL).

\begin{abstract}
Abstrak: Memasuki usianya ke-56, UMS masih harus melakukan perbaikan dan pengembangan dalam proses pembelajaran. Untuk kepentingan perbaikan dan pengembangan tersebut, studi ini dilakukan dengan tujuan untuk memetakan kinerja dosen UMS dalam prencanaan pembelajaran, kinerja dosen UMS dalam pelaksanaan pembelajaraan, dan kinerja dosen UMS dalam evaluasi hasil pembelajaran. Berdasarkan studi deskriptif non-eksperimental berbentuk survei, dengan metode angket, telaah dokumen, dan FGD, studi ini menemukan tiga temuan penting. Pertama, dosen UMS memiliki kinerja yang baik dalam perencanaan pembelajaran. Kedua, kinerja dosen UMS dalam pelaksanaan proses pembelajaran belum sepenuhnya baik, karena belum menggunakan metode pembelajaran yang beragam. Ketiga, kinerja dosen UMS dalam evaluasi hasil pembelajaran cukup baik. Dengan tiga temuan di atas dapat dikatakan bahwa kinerja dosen UMS dalam proses pembelajaran selama ini hampir memenuhi komponen kewajiban yang diminta oleh UU Guru dan Dosen Tahun 2005 dan telah mengacu kepada PP No. 19 tentang Standar Nasional Pendidikan (SNP) Tahun 2005.
\end{abstract}

Kata kunci: Kinerja Dosen; UU Guru dan Dosen; Standar Nasional Pendidikan; Student Centered Learning (SCL).

\section{PENDAHULUAN}

Memasuki usia yang ke-56 Universitas Muhammadiyah Surakarta (UMS) tel- ah mencapai prestasi akademik yang cukup signifikan. Pada tingkat nasional, UMS diakui oleh Dikti Kemendikbud RI sebagai 50 perguruan tinggi di Indonesia yang men- 
janjikan. Pada tingkat regional, UMS dipercaya oleh masyarakat sebagai perguruan tinggi swasta terfavorit di Jawa Tengah. Kini, UMS sedang bertekad menjadikan eksistensinya sebagai perguruan tinggi yang dikenal di dunia, baik dari aspek pendidikan dan pengajaran, penelitian, maupun pengabdiannya kepada masyarakat. Untuk mencapai prestasi akademik yang menggembirakan tersebut tentu semua komponen civitas akdemika UMS baik dosen, karyawan, mahasiswa maupun stakeholders lainnya telah memainkan peran dan kontribusi positif yang tidak kecil. Sebagai contoh komponen dosen, misalnya, merupakan komponen penting dalam proses pencapaian prestasi akademik tersebut baik dari segi dharma pendidikan dan pengajaran, penelitian maupun pengabdian kepada masyarakat.

Di usianya yang ke-56 ini, kegiatan pendidikan dan pembelajaran sebagai fokus kegiatan para dosen di UMS selama ini perlu dikaji pelaksanaannya terutama dikaitkan dengan Undang-Undang Guru dan Dosen Tahun 2005 dan Peraturan Pemerintah RI No. 19 tentang Standar Nasional Pendidikan (SNP) Tahun 2005. Studi ini perlu dilakukan dengan alasan bahwa UMS memerlukan data terkini tentang kinerja proses pembelajaran yang mendesak untuk diperbaharui dan dapat dipertanggungjawabkan secara ilmiah. Dengan demikian, studi yang menekankan pada kinerja proses pembelajaran ini diharapkan memperoleh profil pembelajaran di UMS sebagai bahan peningkatan kualitas pembelajaran di UMS. Peningkatan kualitas pembelajaran ini merupakan salah satu faktor penting dalam peningkatan kualitas proses yang tepat, efektif, dan efisien. Selanjutnya kualitas proses diharapkan dapat meningkatkan kualitas out put.

Studi tentang pembelajaran di perguruan tinggi telah banyak dilakukan oleh para peneliti dari berbagai negara. Pada tahun 1997, misalnya, Hall and Saunders (1997: 271), telah melakukan studi dengan judul Adopting a student-centered approach to management of learning. Dalam studi ini mereka telah menemukan 3 temuan pent- ing tentang kelebihan pembelajaran berbasis Student Centered Learning (CTL). Ketiga temuan tersebut adalah: (1) tingkat partisipasi peserta didik meningkat, (2) motivasi dan prestasi belajar peserta didik pada tahun pertama bertambah tinggi, (3) ada 94\% peserta didik yang meminta para guru mengubah pendekatan pembelajaran yang konvensional.

Di pihak lain, Lea at.al (2003: 322) telah melakukan studi yang berjudul Higher Education Students 'Attitudes to Student Centered Learning Beyond Educational Bulimia'. Dalam sudi ini ia menemukan tujuh kelebihan pembelajaran berbasis SCL di Perguruan Tinggi. Ketujuh kelebihan yang dimaksud adalah: (1) mahasiswa aktif dalam proses pembelajaran, (2) mahasiswa menekankan pada belajar mendalam dan belajar memahami, (3) tanggungjawab dan peran mahasiswa dalam pembelajaran meningkat, (4) kemandirian belajar mahasiswa meningkat, (5) ada saling ketergantungan antara dosen dan mahasiswa, (6) ada hubungan saling menghargai antara dosen dan mahasiswa, dan (7) ada usaha untuk merefleksikan hasil belajar pada mahasiswa dan dosen.

Selanjutnya, pada tahun yang sama, 2003, Lea at.al (2003: 334) telah melakukan studi tentang pembelajaran berbasis SCL di perguraun tinggi dengan judul Higher Education Student 'Attitutes to Student Centered Learning: Beyond Educational Bulimia' in a UK University. Dalam studi ini, Lea et.al menyimpulkan bahwa pembelajaran berbasis SCL sangat efektif dan tepat bagi mahasiswa di Inggris. Hal ini terlihat dari 3 (tiga) hal, yaitu: (1) para mahasiswa sangat respek terhadap pendekatan SCL, (2) mahasiswa tertarik dan menikmati proses pembelajaran yang berlangsung, dan (3) para mahasiswa memiliki tingkat kepercayaan diri yang tinggi.

Pada tahun 2004 Handlesman, et.al. (hlm. 521-522) dari Texas A\&M University telah melakukan studi tentang pembelajaran berbasis SCL di perguruan tinggi dengan judul Scientific Teaching. Dalam studi ini ia menyimpulkan bahwa pembelajaran berbasis SCL berpengaruh positif dalam pen- 
ingkatan kinerja akademik, sikap terhadap mata kuliah, dan prestasi belajar peserta didik. Hal ini dilatarbelakangi oleh 3 (tiga) faktor penting, yaitu: (1) mahasiswa terlibat aktif dalam proses pembelajaran, (2) dosen menggunakan strategi pembelajaran aktif, dan (3) suasana pembelajaran menyenangkan baik bagi peserta didik maupun dosen.

Studi yang hampir serupa telah dilakukan oleh Yong Ping $\mathrm{Xu}$ dengan judul Student-Centered Learning of IC Design in a Project-based Undergraduate Course di Singapore pada 2008. Dalam studi ini ia menyimpulkan bahwa pembelajaran berbasis SCL di perguruan tinggi dapat mendorong peserta didik memiliki motivasi diri yang tinggi dalam kegiatan penyelesaian proyek. Kesimpulan ini didasarkan pada 3 (tiga) hal, yaitu: (1) dosen hanya berperan sebagai fasilitator dalam proses pembelajaran, (2) mahasiswa menyelesaikan proyek secara kolaboratif mulai dari perencanaan, pelaksanaan, sampai pada evaluasi hasil; dan (3) mahasiswa memiliki pengalaman belajar dan keterampilan menganalisis dan memecahkan masalah.

Studi tentang pembelajaran di perguruan tinggi yang mengkaitkan dengan pendekatan SCL di Indonesia telah dilakukan oleh Sekar Ayu Aryani, dkk di lingkungan Universitas Islam Negeri (UIN) Yogyakarta pada 2005. Dalam studinya yang berjudul Studi Evaluatif Program Sosialisasi Pembelajaran di Perguruan Tinggi Tahun 2004 oleh CTSD, Aryani menyimpulkan bahwa pembelajaran berbasis SCL dapat meningkatkan semangat dan kegairahan belajar mahasiswa di UIN Yogyakarta baik secara individual maupun kolaboratif jika dibandingkan dengan pembelajaran berbasis TCL. Namun demikian, Aryani juga menemukan ada beberapa materi pembelajaran yang perlu penyempurnaan sehingga efektivitas pembelajaran berbasis SCL dapat terpenuhi.

Pada 2011 studi tentang pembelajaran di perguruan tinggi telah dilakukan oleh Abdullah Aly di UMS dengan judul: "Penerapan Model Pembelajaran berbasis Student Centered Learning, SCL) di UMS". Dalam studi ini disimpulkan bahwa pener- apan model pembelajaran berbasis SCL di UMS menemui problem pokok, yaitu bahwa pembelajaran berbasis SCL baru dipraktikkan oleh sebagian kecil dari dosen UMS. Sebaliknya, pembelajaran yang dilakukan oleh sebagian besar dosen UMS cenderung berbasis TCL (Teaching Centered Learning). Model pembelajaran berbasis TCL ini memiliki konsep bahwa belajar merupakan kegiatan memperoleh ilmu, sementara mengajar merupakan kegiatan memindahkan pengetahuan (transfer of knowledge) kepada peserta didik sehingga peserta didik pasif, butuh motivasi luar dan dipengaruhi dosen dalam proses pembelajaran. Dengan demikian, dalam proses pembelajaran, peserta didik diharapkan memiliki pemahaman yang sama dengan dosen terhadap pengetahuan yang dipelajari.

Berdasarkan hasil studi di atas diperoleh kesimpulan bahwa pembelajaran yang dilakukan di perguruan tinggi ternyata sangat efektif untuk meningkatkan motivasi dan prestasi hasil belajar para mahasiswa dengan penggunaan pendekatan SCL. Namun demikian, dalam studi tersebut belum dikaitkan dengan kinerja dosen dalam proses pembelajaran. Oleh karena itu, perlu dilakukan studi tentang proses pembelajaran di perguruan tinggi yang mengaitkan kinerja dosen dalam proses pembelajaran.

Dengan mempertimbangkan uraianuraian di atas, studi ini ingin mengkaji seł cara deskriptif profil pembelajaran di UMS dengan fokus pada 3 (tiga) hal, yaitu: (1) kinerja dosen dalam perencanaan pembelajaran, (2) kinerja dosen dalam pelaksanaan pembelajaran, dan (3) kinerja dosen dalam evaluasi hasil pembelajaran. Hasil dari studi deskriptif ini selanjutnya diharapkan dapat bermanfaat untuk menyusun strategi pent1 ingkatan kualitas pembelajaran di lingkungan UMS, merancang proses pembelajaran yang sesuai, efektif, dan efisien dalam sasaran pencapaian kualitas outputnya, dan strategi pembinaan dosen, khususnya pada bidang pembelajaran.

Untuk memetakan kinerja dosen UMS dalam perencanaan pembelajaran, pelaksanaan proses pembelajaran, dan evalu- 
asi hasil pembelajaran di UMS, studi ini pertama-tama menggunakan teori kinerja menurut beberapa peneliti perilaku organisasi. Di antaranya adalah menurut Stolovitck dan Keeps (dalam Veithzal Rivai, 2005) bahwa kinerja merupakan "seperangkat hasil yang dicapai dan merujuk pada tindakan pencapaian serta pelaksanaan suatu pekerjaan yang diminta." Definisi senada dikemukakan oleh Hersley dan Blanchard (dalam Veithzal Rivai, 2005) bahwa kinerja adalah "suatu fungsi dari motivasi dan kemampuan untuk menyelesaikan tugas dan pekerjaan seseorang harus memiliki derajad kesediaan dan tingkat kemampuan tertentu." Definisi lebih rinci dikemukakan oleh Anak Agung (2005: 18). Menurutnya, kinerja dosen dapat dipahami sebagai "penampilan kerja dosen dalam penyelenggaraan pendidikan dan pengajaran yang menggambarkan kualitas pekerjaan, jumlah pekerjaan, pengetahuan tugas pekerjaan, inisiatif, kerjasama, tanggungjawab, tingkat kehadiran, dan waktu penyelesaian tugas."

Selanjutnya, studi ini menggunakan konsep dasar tentang kedudukan, tugas utama, fungsi, dan kewajiban dosen yang terdapat pada pasal-pasal dalam UU Guru dan Dosen. Hal ini dengan alasan bahwa produk hukum tersebut harus dijadikan pedoman dan dipraktikkan di berbagai lembaga pendidikan di Indonesia. Adapun kedudukan dosen dalam pasal-pasal tersebut adalah sebagai pendidik professional dan ilmuwan dengan tugas utama mentransformasikan, mengembangkan, dan menyebarluaskan ilmu pengetahuan, teknologi, dan seni, serta pengabdi kepada masyarakat berfungsi untuk meningkatkan mutu pendidikan nasional. Dalam kaitan tugas utama dan fungsi dosen sebagai agen pembelajaran, pengembang ilmu pengetahuan, teknologi, dan seni, maka dosen memiliki kewajiban pokok dalam pembelajaran, yaitu: merencanakan, melaksanakan proses pembelajaran, serta menilai dan mengevaluasi hasil pembelajaran (Pasal 60 UU Guru dan Dosen, 2005).

Berdasarkan uraian kepada kedudukan, tugas utama, fungsi, kewajiban dosen yang terdapat pada pasal-pasal dalam UU Guru dan Dosen serta definisi kinerja menurut pakar ilmu organisasi di atas, maka dapat dikatakan bahwa yang dimaksud dengan kinerja dosen dalam pembelajaran di sini adalah "penampilan kerja dosen dalam merencanakan, melaksanakan proses pembelajaran, serta menilai dan mengevaluasi hasil pembelajaran berdasarkan pada tindakan pencapaian dan pelaksanaan tugas dan kewajiban pokoknya."

Perencanaan pembelajaran yang dikaitkan dengan kinerja dosen dapat diamati dari desain pembelajaran yang disusun. Secara teoritik desain pembelajaran memuat 4 (empat) komponen pokok, yaitu: tujuan pembelajaran, materi pembelajaran, metode pembelajaran, dan evaluasi hasil belajar mahasiswa. Jika dosen menyusun desain pembelajaran dengan empat komponen tersebut, maka ia telah menunjukkan kinerja dosen sesuai amanat yang diminta oleh UU Guru dan Dosen. Sebagai tambahan, perencanaan pembelajaran yang disusun oleh dosen harus mengacu kepada standar proses sesuai dengan Peraturan Pemerintah No. 19 Tahun 2005 tentang Standar Nasional Pendidikan (SNP). Dalam PP tersebut terutama pada Pasal 20 disebutkan bahwa perencanaan proses pembelajaran "meliputi silabus dan rencana pelaksanaan pembelajaran yang sekurang-kurangnya memuat tujuan pembelajaran, materi ajar, metode pengajaran, sumber belajar, dan penilaian hasil belajar". Perencanaan proses pembelajaran tiap mata kuliah yang disusun oleh dosen di atas dimuat dalam Rencana Pembelajaran Semester (RPS) atau istilah lain yang berlaku di perguruan tinggi yang bersangkutan.

Sementara itu, pelaksanaan proses pembelajaran yang dihubungkan dengan kinerja dosen dapat dilihat dari kesesuaian pelaksanaan proses pembelajaran dengan desain pembelajaran yang telah disusun dan sesuai dengan jumlah kehadiran yang harus dipenuhi. Selain itu, proses pembelajaran yang telah dilakukan oleh dosen seharusnya bersifat interaktif, menyenangkan, menantang, dan memotivasi mahasiswa 
untuk berpartisipasi aktif, serta memberikan kesempatan atas prakarsa, kreativitas, dan kemandirian sesuai dengan bakat, minat dan perkembangan fisik serta psikologis mahasiswa. Dengan ungkapan lain, proses pembelajaran yang dilakukan dosen harus mampu membangun suasana pembelajaran yang menyenangkan dan dapat memotivasi mahasiswa untuk belajar secara mandiri. Dalam hubungan ini, seorang dosen dapat dikatakan berpenampilan kerja yang baik jika ia melakukan proses pembelajaran berdasarkan pada desain pembelajaran yang telah direncanakan dan jumlah kehadiran yang seharusnya. Sebagai tambahan, seorang dosen yang mampu menciptakan suasana pembelajaran yang menyenangkan dan mampu memotivasi mahasiswa untuk belajar secara mandiri berarti ia telah memenuhi ketentuan kinerja dosen yang telah diamanatkan oleh UU Guru dan Dosen.

Lebih jauh tentang pelaksanaan proses pembelajaran PP tentang SNP mengamanatkan bahwa seorang dosen dalam melaksanakan proses pembelajaran "harus memperhatikan jumlah maksimal peserta didik per kelas dan beban mengajar maksimal per pendidik, rasio maksimal buku teks pelajaran setiap peserta didik, dan rasio maksimal jumlah peserta didik setiap pendidik (PP SNP Pasal 21 Ayat 1). Selanjutnya pada Ayat 2 disebutkan bahwa "pelaksanaan proses pembelajaran dilakukan dengan mengembangkan budaya membaca dan menulis". Adapun dari segi urutannya, proses pembelajaran yang dilakukan oleh dosen mencakup 3 urutan kegiatan, yaitu: kegiatan pendahuluan, kegiatan inti, dan penutup. Kegiatan pendahuluan berfungsi untuk memberikan informasi yang komprehensif tentang rencana, pelaksanaan, dan hasil evaluasi pembelajaran. Kegiatan inti berfungsi untuk menjelaskan kegiatan belajar dan metode yang digunakan untuk mencapai target pembelajaran. Sedangkan kegiatan penutup berfungsi untuk refleksi dan tolok ukur pencapaian target pembelajaran.

Adapun pelaksanaan evaluasi hasil belajar yang dikaitkan dengan kinerja dosen dapat diuji dari kemampuan alat evaluasi untuk mengukur kualitas pencapaian target pembelajaran yang telah ditetapkan pada desain pembelajaran sebelumnya. Dalam kaitan ini, seorang dosen dapat dikatakan telah memenuhi kriteria penampilan kerja dosen yang baik jika evaluasi hasil belajar mahasiswa yang telah dilakukan menghasilkan pencapaian kompetensi yang telah diharapkan oleh sang dosen. Sebagai tambahan, seorang dosen dapat dikatakan berpenampilan kerja yang baik jika ia bertanggung jawab terhadap hasil evaluasi pembelajaran yang telah dicapai dan telah memenuhi satuan waktu penyelesaian tugas yang diminta.

Lebih jauh, seorang dosen dalam melakukan evaluasi hasil belajar perlu mengacu kepada PP SNP Tahun 2005. Dalam PP tersebut Pasal 22 disebutkan bahwa seorang dosen pada saat melakukan "penilaian hasil belajar menggunakan berbagai teknik penilaian sesuai dengan kompetensi dasar yang harus dikuasai. Teknik penilaian tersebut dapat berupa tes tertulis, observasi, tes praktik, dan penugasan perseorangan atau kelompok". (PP SNP Pasal 22 Ayat 1 dan 2). Selain mengacu kepada kompetensi dasar, penilaian hasil belajar yang dilakukan oleh dosen harus berfungsi untuk menentukan kualifikasi atas perencanaan, pelaksanaan, dan pengendalian proses pembelajaran, serta capaian pembelajaran setelah mahasiswa menjalani proses pembelajaran.

\section{METODE PENELITIAN}

Studi ini merupakan penelitian lapangan yang bersifat kuantitatif dengan pendekatan deksriptif non-eksperimental. Dikatakan deskriptif, karena studi ini diarahkan untuk menggambarkan fenomena proses pembelajaran di lingkungan UMS yang berlangsung pada 2013-2014 ini. Penggambaran fenomena tersebut bukan bersifat individual tetapi bersifat kelompok dan penggambarannya menggunakan angka-angka. Selain bersifat deskrptif, studi ini juga bersifat non-eksperimental berbentuk survei. Dikatakan non-eksperimental, 
karena penggambaran dalam studi ini tidak memberikan perlakukan dan manipulasi, tetapi menggambarkan kegiatan proses pembelajaran secara apa adanya.

Adapun bentuk survei dipilih dalam penelitian ini dengan tiga alasan pokok. Pertama, studi ini berusaha untuk mengumpulkan informasi berbentuk opini dari sejumlah besar responden terhadap isu yang terkait dengan proses pembelajaran di lingkungan UMS. Kedua, studi ini memilih bentuk survei karena data yang dikumpulkan berkenaan dengan sikap, pendirian, dan pendapat para responden terkait dengan proses pembelajaran di UMS. Ketiga, penggunaan survei cukup efisien dan dapat menghimpun data tentang pendapat para peserta PPL tentang kinerja dosen dalam proses pembelajaran dan memungkinkan penarikan generalisasi terhadap sikap semua mahasiswa UMS terhadap hal tersebut.

Lokasi studi ini adalah di UMS dengan menekankan pada beberapa program studi di dua fakultas: FKIP dan FAI. Populasi dan sumber data dalam studi ini meliputi populasi terukur dan populasi target. Populasi terukur dipilih karena populasi ini secara riil dijadikan dasar dalam penentuan sampel, dan secara langsung menjadi lingkup sasaran keberlakuan kesimpulan. Adapun populasi terukur di sini adalah semua mahasiswa UMS yang tersebar pada 12 fakultas dan 44 program studi. Sementara itu, populasi target dipilih dengan alasan bahwa populasi ini memiliki kesamaan karakteristik dengan populasi terukur. Adapun populasi target dan sumber data dalam studi ini adalah semua mahasiswa peserta Program Pengalaman Lapanagan (PPL) pada 2013 yang berjumlah 640 orang. Populasi target dan sumber data lainnya adalah beberapa ketua Prodi, KaPMP, dosen, dan mahasiswa bukan peserta PPL di lingkungan UMS.

Data yang dikumpulkan berupa penilaian kinerja dosen dalam pembelajaran. Data dikumpulkan melalui metode gabungan, yaitu metode angket tertutup, metode Focused Group Discussion (FGD), dan metode studi dokumenter. Metode an- gket tertutup dalam studi ini diberikan kepada semua mahasiswa peserta PPL pada 2013 yang berjumlah 640 orang. Adapun alasan penggunaan angket tertutup adalah bahwa pertanyaan atau pernyataan-pernyataan yang diajukan kepada responden dilengkapi dengan alternatif jawaban yang tinggal dipilih oleh responden. Responden tidak bisa memberikan jawaban atau respon lain kecuali yang telah tersedia sebagai alternatif jawaban. Alternatif jawaban yang digunakan dalam angket ini berbentuk skala deskriptif dengan pola skala sikap dari Likert. Hal ini didasarkan pada fakta bahwa pertanyaan atau pernyataan yang diajukan kepada responden menuntut jawaban berbentuk skala persetujuan atau penolakan terhadap isi pertanyaan atau pernyataan tersebut. Dalam angket ini, penerimaan atau penolakan responden dinyatakan dalam bentuk persetujuan responden yang dimulai dari sangat setuju, setuju, ragu-ragu, dan tidak setuju. Bentuk ini digunakan untuk menggali data kinerja dosen dalam proses pembelajaran. Bentuk persetujuan tersebut dilambangkan dengan angka 1, 2, 3, dan 4.

Metode lain yang digunakan untuk menggali data dalam studi ini adalah metode FGD. Metode ini dilakukan kepada ketua Prodi, KaPMP, dosen, dan mahasiswa bukan peserta PPL di lingkungan UMS. FGD dilakukan secara kelompok dalam suatu forum diskusi terfokus selama tiga jam lebih-tepatnya dari jam 09.0012.30 WIB bertempat di gedung G Fakultas Ekonomi dan Bisnis UMS. Pertanyaan yang diajukan dalam FGD secara garis besar terfokus pada sejumlah pertanyaan terkait kinerja dosen dalam pembelajaran yang meliputi persiapan, pelaksanaan, dan evaluasi pembelajaran. Metode terakhir untuk pengumpulan data adalah metode studi dokumenter. Dokumen yang ditelaah dalam studi ini adalah dokumen tertulis yang sesuai dengan tujuan dan fokus studi. Adapun dokumen yang dipilih adalah dokumen nilai IKAD dosen, dokumen laporan tahunan Rektor UMS, dan dokumen SOP pembelajaran yang berlaku di UMS.

Data yang terkumpul dianalisis dengan 
tiga langkah. Pertama, melakukan tabulasi data yang diperoleh dari hasil angket. Sebagian data yang dianalisis ada yang diorganisasi dan dikelompokkan berdasarkan kriteria persentase. Kedua, menyusun fakta-fakta hasil temuan lapangan dalam bentuk tabel, grafik, serta deksripsi dan narasi yang diperoleh dari angket dan FGD. Ketiga, menafsirkan data berdasarkan dialog dengan kerangka teori yang dipilih. Dalam melakukan interpretasi data hasil FGD dan deksripsi dari angket, digunakan pola analytic induction, diawali dengan interpretasi awal atas dasar data dari angket dan selanjutnya diperkaya berdasarkan data dari FGD.

\section{HASIL PENELITIAN DAN PEMBAHA- SAN}

Pada bagian ini dipaparkan deskripsi data tentang kinerja dosen UMS dalam proses pembelajaran. Tabel 1 menunjukkan bahwa kinerja dosen UMS dalam proses pembelajaran di sini dilihat dari 3 (tiga) aspek pembelajaran, yaitu: aspek perencanaan pembelajaran, aspek proses pelaksanaan pembelajaran, dan aspek evaluasi hasil pembelajaran. Aspek perencanaan pembelajaran didekati dari 3 (tiga) hal, yaitu: kontrak belajar, ketersediaan Rencana Mutu Pembelajaran (RMP), serta informasi referensi dan pemutakhiran bahan ajar yang dilakukan oleh dosen pengampu di UMS. Adapun aspek proses pelaksanaan proses pembelajaran di sini ditekankan pada 4 (empat) poin penting. Keempat poin tersebut adalah kesesuaian pembelajaran dengan RMP yang ada, penggunaan metode pembelajaran, penggunaan media pembelajaran, dan antusiasme dalam pembelajaran. Sementara itu, aspek hasil evaluasi pembelajaran diarahkan pada 3 (tiga) hal. Ketiga hal tersebut adalah keaktifan memotivasi mahasiswa dalam pembelajaran, kesediaan mengoreksi tugas yang dikerjakan mahasiswa, dan keterbukaan terhadap kritik dari para mahasiswa.

Tabel 1. Kinerja Dosen UMS dalam Pembelajaran Berdasarkan Distribusi Frekuensi Skor Per Item Pertanyaan

\begin{tabular}{|c|c|c|c|c|c|c|c|c|c|c|}
\hline \multirow{3}{*}{ No } & \multirow{3}{*}{ Item Pertanyaan } & \multirow{3}{*}{$\sum$} & \multicolumn{8}{|c|}{ Skala Penilaian Responden } \\
\hline & & & \multicolumn{2}{|c|}{ TS } & \multicolumn{2}{|c|}{$\mathrm{RR}$} & \multicolumn{2}{|c|}{$S$} & \multicolumn{2}{|c|}{ SS } \\
\hline & & & $\sum$ & $\%$ & $\sum$ & $\%$ & $\sum$ & $\%$ & $\sum$ & $\%$ \\
\hline 1 & Kontrak belajar & 653 & 33 & 5 & 83 & 13 & 345 & 53 & 192 & 29 \\
\hline 2 & Terbuka terhadap kritik & 652 & 62 & 10 & 106 & 16 & 330 & 51 & 154 & 24 \\
\hline 3 & $\begin{array}{l}\text { Keaktifan memotivasi maha- } \\
\text { siswa }\end{array}$ & 651 & 49 & 8 & 106 & 16 & 314 & 48 & 182 & 28 \\
\hline 4 & Kesesuaian RMP & 649 & 43 & 7 & 165 & 25 & 327 & 50 & 114 & 18 \\
\hline 5 & $\begin{array}{l}\text { Kesanggupan mengoreksi } \\
\text { tugas mahasiswa }\end{array}$ & 638 & 51 & 8 & 124 & 19 & 334 & 52 & 129 & 20 \\
\hline 6 & $\begin{array}{l}\text { Metode pembelajaran tidak } \\
\text { bervariasi }\end{array}$ & 651 & 211 & 32 & 166 & 25 & 199 & 31 & 75 & 12 \\
\hline 7 & $\begin{array}{l}\text { Antusiasme dalam pembela- } \\
\text { jaran }\end{array}$ & 652 & 69 & 11 & 145 & 22 & 344 & 53 & 94 & 14 \\
\hline 8 & $\begin{array}{l}\text { Informasi sumber pembelaja- } \\
\text { ran }\end{array}$ & 650 & 39 & 6 & 128 & 20 & 361 & 56 & 122 & 19 \\
\hline 9 & Media pembelajaran menarik & 651 & 89 & 14 & 181 & 28 & 276 & 42 & 155 & 16 \\
\hline 10 & Pemutakhiran bahan ajar & 651 & 44 & 7 & 123 & 19 & 326 & 50 & 158 & 24 \\
\hline
\end{tabular}


Kinerja Dosen UMS dalam Perencanaan Pembelajaran

Grafik 1 menunjukkan deskripsi kinerja dosen UMS dalam aspek perencanaan pembelajaran. Dilihat dari aspek ini, kinerja dosen UMS dinilai baik oleh para mahasiswa. Terbukti ada 537 responden (82 \%) yang mengakui para dosen UMS telah membuat kontrak belajar pada awal pembelajaran. Bukti lainnya adalah ada 441 responden $(68 \%)$ yang mencatat para dosen UMS telah memiliki RMP. Bukti terakhir adalah terkait dengan informasi referensi dan pemutakhiran bahan dalam pembelajaran. Ada 483 responden (75\%) yang menilai para dosen UMS telah menunjukkan infromasi sumber pembelajaran atau referensi kepada para mahasiswa, dan ada 484 responden $(74 \%)$ yang menyebutkan bahwa dosen UMS telah melakukan pemutakhiran bahan pembelajarannya.

Kinerja dosen UMS dalam perencanaan pembelajaran sebagaimana tergambar pada grafik 1 telah menunjukkan kesesuaian dengan teori desain pembelajaran yang terdiri atas: tujuan, materi, metode, dan evaluasi pembelajaran. Desain pembelajaran yang disusun oleh dosen UMS ini dimuat dalam perangkat pembelajaran yang disebut RMP (Rencana Mutu Pembelajaran). Jika dilihat dari substansinya, RMP dosen UMS telah memenuhi komponen yang diminta oleh UU Guru dan Dosen Tahun 2005. Secara lebih rinci, RMP yang telah disusun oleh dosen UMS ternyata juga mengacu kepada PP No. 19 tentang Standar Nasional Pendidikan (SNP) yang meliputi silabus dan rencana pelaksanaan pembelajaran yang sekurang-kurangnya memuat tujuan pembelajaran, materi ajar, metode pengajaran, sumber belajar, dan penilaian hasil belajar. Desain perencanaan pembelajaran ini menurut mahasiswa dijelaskan oleh dosen pada kontrak belajar di awal perkuliahan.

\section{Grafik 1. Kinerja Dosen UMS dalam Perencanaan Pembelajaran}

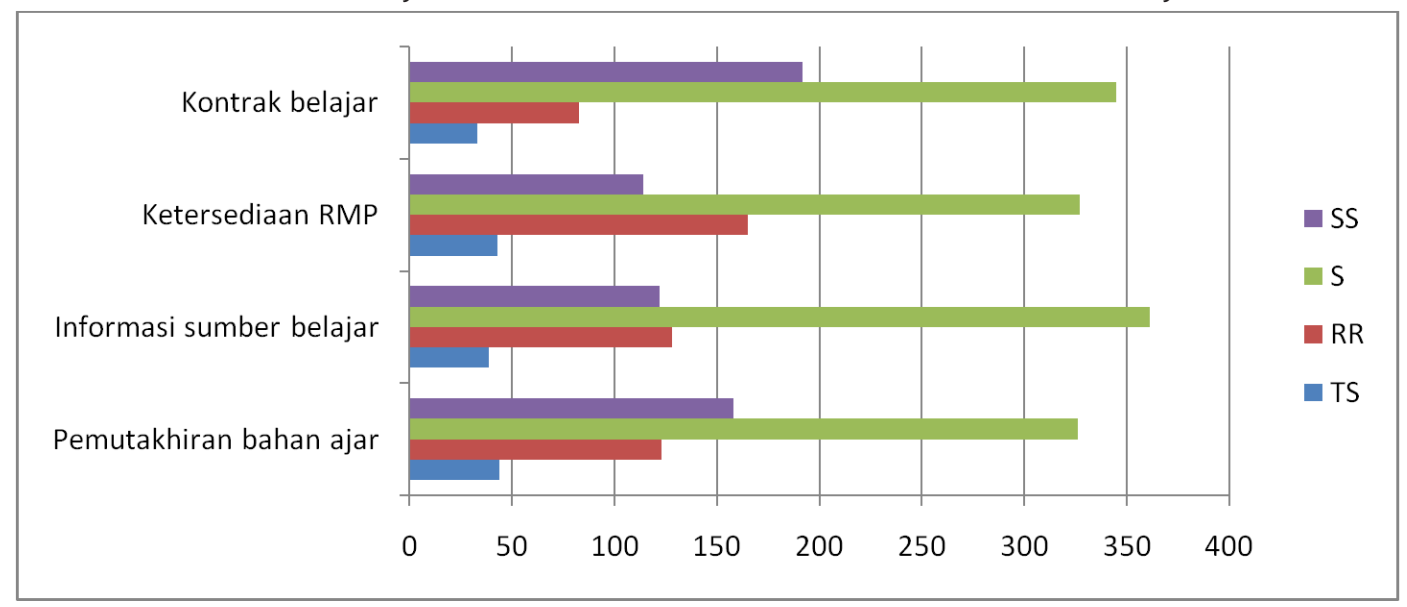

Berdasarkan fakta tentang keberadaan RMP, substansi, dan penjelasan dari dosen tersebut para mahasiswa memberikan penilaian bahwa RMP yang disusun oleh dosen sangat jelas, informatif, dan aktual dari sisi referensi yang dipergunakannya. Penilaian ini disampaikan oleh beberapa mahasiswa dan dosen pada saat Focused Group Discussinon (FGD). Dengan demikian dapat dikatakan bahwa kinerja dosen UMS dalam aspek perencanaan pembelajaran ini cukup baik, karena RMP yang disusun se- suai dengan teori desain pembelajaran di satu sisi, dan pada sisi yang lain isi RMP tersebut telah memenuhi komponen perencanaan yang diminta oleh undang-undang dan peraturan yang berlaku di perguruan tinggi di Indonesia.

\section{Kinerja Dosen UMS dalam Pelaksanaan Pembelajaran}

Dilihat dari aspek pelaksanaan proses pembelajarannya, grafik 2 menunjukkan bahwa kinerja dosen UMS dalam pros- 
es pembelajaran belum sepenuhnya baik. Hal ini dapat dilihat dari persepsi mahasiswa terhadap 4 (empat) poin. Poin pertama menunjukkan ada 441 responden (68\%) yang mencatat para dosen UMS telah melakukan proses pembelajaran sesuai dengan RMP yang telah disusun. Poin kedua, ada 274 responden (43\%) yang telah mencatat bahwa dosen UMS tidak menggunakan metode pembelajaran yang beragam. Dengan kata lain, mereka telah menerapkan pembelajaran aktif (active learning). Dari sisi ini, ada 477 responden (73\%) yang mencatat bahwa dosen UMS telah menerapkan pembelajaran aktif dengan baik. Poin ketiga, ada 438 responden (67\%) yang menyatakan bahwa dosen UMS telah menunjukkan antusisme yang tinggi dalam proses pembelajaran. Poin terakhir, ada 431 responden (58\%) yang menilai para dosen UMS telah menggunakan media pembelajaran yang menarik dan efektif.

\section{Grafik 2. Kinerja Dosen UMS dalam Pelaksanaan Pembelajaran}

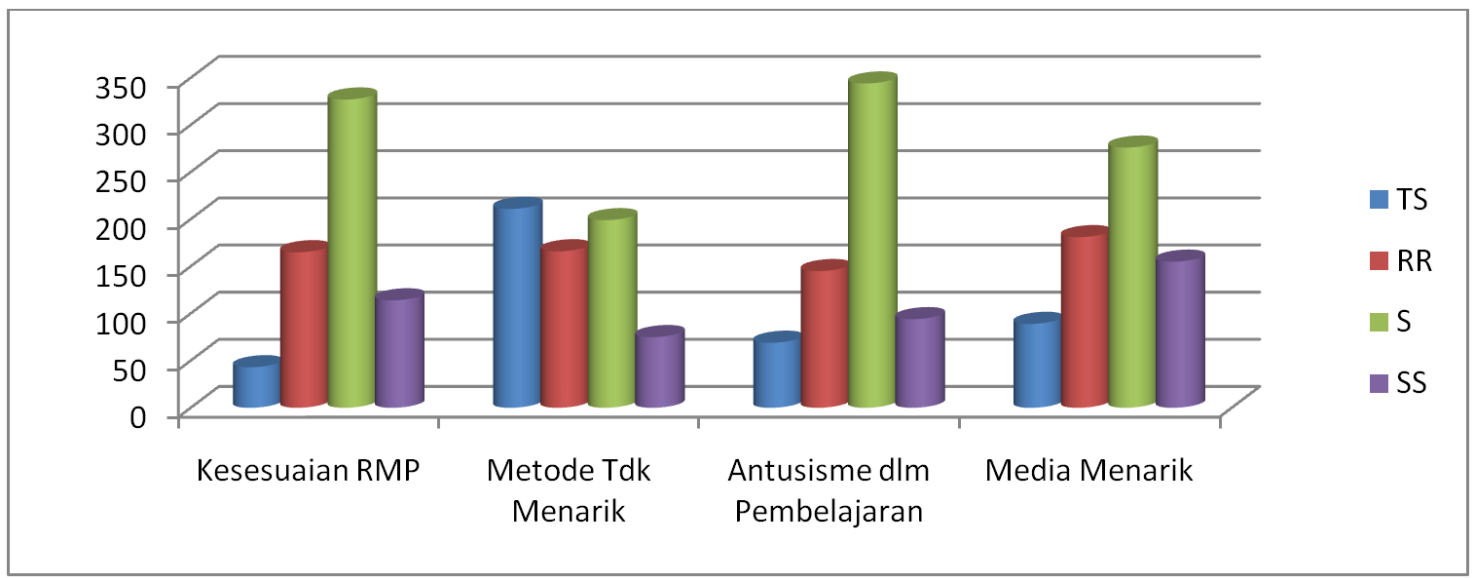

Proses pembelajaran yang dilakukan oleh para dosen UMS sebagaimana tergambar pada grafik 2 jika dikaji dengan teori perencanaan pembelajaran, maka dapat dikatakan bahwa para dosen UMS telah melakukan proses pembelajaran berbasis pada RMP yang telah disusun. Dari aspek ini, proses pembelajaran yang dilakukan oleh para dosen di UMS sesuai dengan desain pembelajaran yang telah dijelaskan kepada para mahasiswa pada saat kontrak belajar di awal perkuliahan. Pelaksanaan proses pembelajaran seperti ini telah mengacu kepada butir-butir kewajiban dosen yang termuat dalam UU Guru dan Dosen Tahun 2005.

Sementara itu, dari sisi standar prosesnya, para dosen UMS telah mampu mengelola pembelajaran yang interaktif, menyenangkan, menantang, dan memotivasi mahasiswa untuk berpartisipasi aktif dalam proses pembelajaran. Selain itu, mereka juga telah memberikan kesempatan atas prakarsa, kreativitas, dan kemandirian sesuai dengan bakat, minat, dan perkembangan fisik serta psikologis mahasiswa. Faktor pentingnya terletak pada penggunaan metode dan media yang menarik dan efektif dalam proses pembelajaran. Jika hal tersebut dikaji dengan teori standar proses pembelajaran, maka dapat dikatakan bahwa para dosen UMS telah melakukan proses pembelajaran yang mengacu kepada standar proses yang termuat dalam PP tentang SNP Tahun 2005.

Berdasarkan hasil telaah hasil studi tentang pelaksanaan proses pembelajaran yang dilakukan oleh para dosen UMS dan kajian pustaka tentang standar proses di atas, maka dapat diperoleh poin penting bahwa kinerja dosen UMS dalam pelaksanaan proses pembelajaran cukup baik. Analisis ini dibenarkan oleh beberapa dosen dan para mahasiswa pada saat triangulasi data 
dalam FGD hasil studi. Hasil analisis ini menunjukkan adanya benih-benih yang menggembirakan dari pelaksanaan proses pembelajaran di UMS. Dikatakan menggembirakan karena para dosen UMS telah melakukan proses pembelajaran sesuai dengan tuntutan UU Guru dan Dosen serta standar proses dalam SNP Tahun 2005.

\section{Kinerja Dosen UMS dalam Evaluasi Hasil Pembelajaran}

Dilihat dari aspek evaluasi hasil pembelajarannya, grafik 3 menunjukkan bahwa kinerja dosen UMS dalam evaluasi hasil pembelajaran ternyata cukup baik. Hal ini dapat dilihat dari 3 (tiga) bukti. Bukti pertama, ada 484 responden (75\%) yang mengakui para dosen UMS memiliki sikap terbuka terhadap kritik dan feedback dari para mahasiswa. Bukti kedua, ada 496 responden $(76 \%)$ yang menilai dosen UMS telah aktif memotivasi para mahasiswa dalam proses pembelajaran. Bukti ketiga, ada 463 responden $(72 \%)$ yang telah mencatat bah- wa dosen UMS memiliki kesanggupan untuk mengoreksi tugas yang dikerjakan oleh para mahasiswa.

Pelaksanaan evaluasi hasil pembelajaran yang dilakukan oleh para dosen UMS sebagaimana dipaparkan pada grafik 3 jika dikaji dengan teori dan kajian pustaka tentang evaluasi hasil pembelajaran, maka dapat dikatakan bahwa para dosen UMS telah melakukan evaluasi hasil pembelajaran berbasis pada kompetensi dasar dan indikator yang ada dalam RMP. Sementara itu, dari standar penilaiannya, para dosen UMS telah melakukan evaluasi hasil pembelajaran untuk menentukan kualifikasi atas perencanaan, pelaksanaan, dan pengendalian proses, serta capaian pembelajaran setelah mahasiswa mengikuti proses pembelajaran. Hal ini dapat dilihat dari 2 (dua) hal, yaitu: kesanggupan mengoreksi tugas yang dikerjakan oleh para mahasiswa, dan kesediaan menerima kritik dan feedback dari para mahasiswa.

\section{Grafik 3. Kinerja Dosen UMS dalam Evaluasi Pembelajaran}

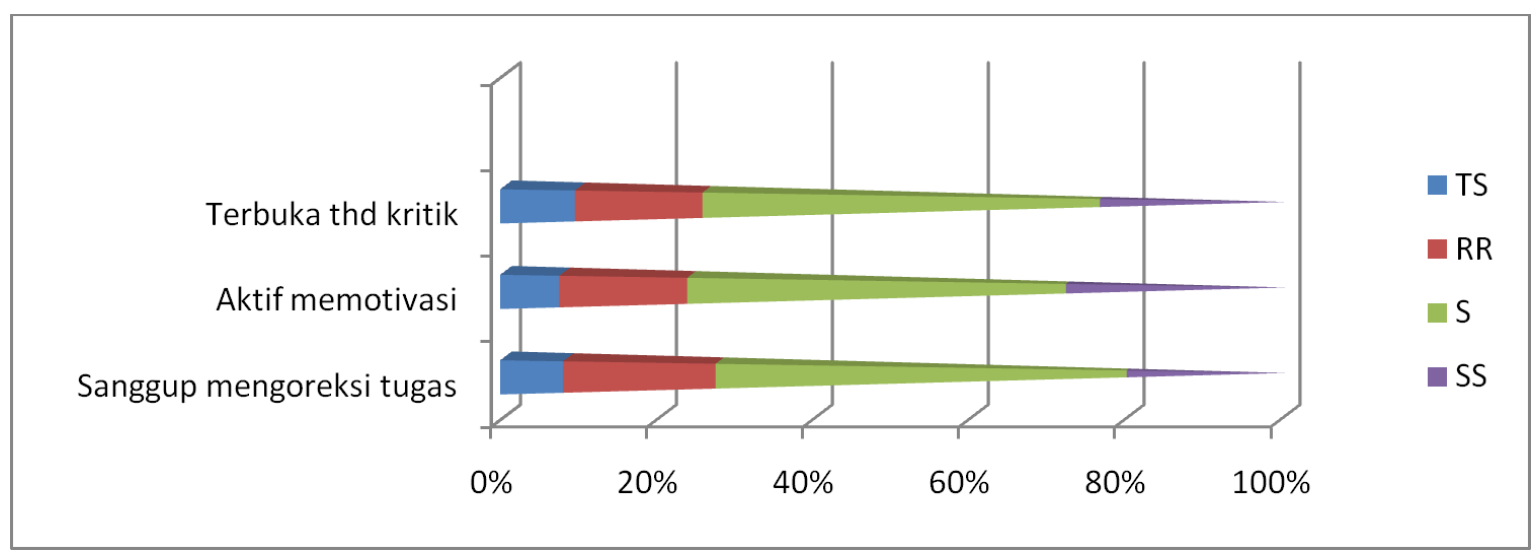

Berdasarkan pada deskripsi hasil studi tentang pelaksanaan evaluasi hasil pembelajaran yang dilakukan oleh para dosen UMS dan kajian pustaka tentang standar penilaian menurut ketentuan UU Guru dan Dosen serta standar penilaian dalam PP SNP Tahun 2005, maka dapat diperoleh poin penting bahwa kinerja dosen UMS dalam pelaksanaan evaluasi hasil pembelajaran cukup baik. Analisis ini dibenarkan oleh beberapa mahasiswa dan bebera- pa dosen-yang mewakili sebagai KaPMP maupun ketua prodi-pada saat triangulasi data dalam FGD hasil studi. Hasil analisis ini menunjukkan bahwa pelaksanaan evaluasi hasil pembelajaran yang dilakukan oleh dosen UMS telah memenuhi unsur legalitas-formal. Dikatakan demikian karena para dosen UMS dalam melakukan evaluasi hasil pembelajaran sesuai dengan tuntutan UU Guru dan Dosen serta standar proses dalam SNP Tahun 2005. 


\section{KESIMPULAN}

Berdasarkan hasil studi dan pembahasan di atas studi ini menghasilkan 3 (tiga) temuan penting. Pertama, bahwa kinerja dosen UMS dalam perencanaan pembelajaran cukup baik. Hal ini dapat dilihat dari penilaian para mahasiswa bahwa para dosen UMS telah membuat kontrak belajar pada awal pembelajaran, para dosen UMS telah memiliki RMP, dan para dosen UMS telah menunjukkan infromasi sumber pembelajaran atau referensi kepada para mahasiswa, serta para dosen UMS telah melakukan pemutakhiran bahan pembelajarannya. Kedua, bahwa kinerja dosen UMS dalam proses pembelajaran belum sepenuhnya baik. Hal ini dapat dilihat dari persepsi mahasiswa bahwa para dosen UMS telah melakukan proses pembelajaran sesuai dengan RMP yang telah disusun, para dosen UMS belum menggunakan metode pembelajaran yang beragam, para dosen UMS telah menerapkan pembelajaran aktif dengan baik, para dosen UMS telah menunjukkan antusisme yang tinggi dalam proses pembelajaran, dan para dosen UMS telah menggunakan media pembelajaran yang menarik dan efektif. Ketiga, bahwa kinerja dosen UMS dalam evaluasi hasil pembelajaran ternyata cukup baik. Hal ini dapat dilihat dari 3 (tiga) bukti dari para mahasiswa, bahwa para dosen UMS memiliki sikap terbuka terhadap kritik dan feedback dari para mahasiswa, para dosen UMS telah aktif memotivasi para mahasiswa dalam proses pembelajaran, dan para dosen UMS memiliki kesanggupan untuk mengoreksi tugas yang dikerjakan oleh para mahasiswa.

Dengan tiga temuan di atas dapat dikatakan bahwa kinerja dosen UMS dalam proses pembelajaran selama ini telah memenuhi komponen kewajiban yang diminta oleh UU Guru dan Dosen Tahun 2005 dan telah mengacu kepada PP No. 19 tentang Standar Nasional Pendidikan (SNP) Tahun 2005. Berdasarkan temuan di atas, berikut ini disampaikan saran atau rekomendasi yang perlu disampaikan kepada para dosen UMS. Para dosen UMS agar dalam kegiatan pembelajaran terus mempertahankan kinerjanya yang sudah baik, seperti menyampaikan sistem perkuliahan pada awal perkuliahan secara jelas, menunjukkan sumber pembelajaran yang digunakan, memotivasi mahasiswa untuk aktif dalam perkuliahan, bersikap terbuka dalam menerima kritik dan saran dari mahaiswa, melakukan koreksi atas tugas yang diberikan kepada mahasiswa, dan mengembangkan (updating) bahan ajar sesuai kebutuhan. Sebaliknya diharapkan para dosen UMS untuk terus meningkatkan kinerjanya dalam empat hal: (a) mengajar sesuai dengan Rencana Mutu Pembelajaran (RMP), (b) menggunakan metode pembelajaran yang tidak monoton, bervariasi, dan menarik; (c) bersikap yang dapat mendorong para mahasiswa bersemangat, dan antusias, serta (d) agar menggunakan media pembelajaran yang lebih menarik dan lebeih efektif.

\section{DAFTAR PUSTAKA}

Agung, Anak \& Irfan. 2005. Analisis Faktor-Faktor Yang Berhubungan dengan Kinerja Dosen. Jakarta: Bina Rupa Aksara.

Anita, Lie. 2002. Cooperative Learning, Mempraktikkan Cooperative Learning di Ruang-ruang Kelas. Jakarta: Grasindo.

Aryani, Sekar Ayu, dkk. 2005. Studi Evaluatif Program Sosialisasi Pembelajaran di Perguruan Tinggi Tahun 2004 oleh CTSD. Yogyakarta: LPPM UIN Sunan Kalijaga.

Bafadhal, ibrahim. 2003 dalam Robins, S.P. 2003. Perilaku Organisasi dan Indeks dan Kelompok. Bandung: Rosdakarya. 
Dirjen Dikti. 2001. Teori Belajar dan Motivasi. Jakarta: Universitas Terbuka.

Djuwita, T.M. 2004. Pengaruh Strategi Pengembangan Dosen Perguruan Tinggi. Jakarta: Binarupa Aksara.

Effendi, Sofian. 2003. Pengembangan Sumber Daya Manusia di Perguruan Tinggi. Jakarta: Rineka Cipta.

Hadi, Syamsul \&Mahmudi. 2005. Manajemen Kinerja Sektor Publik. Jakarta: Akademi Manajemen Indonesia.

Handelsman, J., Ebert-May, D., Beichner, R., Bruns, P., Chang, A., DeHaan, R., et.al. 2004. "Scientific teaching", dalam The International Journal of Science 304(5670), 521-522.

Mangkunegara, AP. 2006. Evaluasi Kinerja SDM. Bandung: Refika Aditama.

Muhibbin, Syah. 2003. Psikologi Pendidikan dengan Suatu Pendekatan Baru. Bandung: PT Remaja Rosdakarya.

Nurgiyantoro, B., dkk. 2005. Statistik Terapan Penelitian Ilmu dan Organisasi. Jurnal Poltek Yogyakarta.

Peraturan Menteri Pendidikan dan Kebudayaan RI Nomor 19 Tahun 2005 tentang Standar Nasional Pendidikan (SNP).

Rivai, Veithzal. 2005. Analisis Faktor ysng Berpengaruh terhadap Kinerja Organisasi. Jakarta: Gramedia.

Slavin. 1994 dalam Ratnawati, Y. 2002. Motivasi Faktor Kunci untuk Meningkatkan Kinerja Organisasi. Jakarta: Gramedia.

Syukri, Fathuddin, dkk. 2012. Upaya Dosen dalam Optimalisasi Pembelajaran Ditinjau dari Heterogenitas Karakteristik Mahasiswa. Yogyakarta: Jurusan Pendidikan Teknik Mesin FT UNY.

Undang-Undang Republik Indonesia No. 14 Tahun 2005 tentang UU Guru dan Dosen.

Utari, Rahmania. 2013. Belajar Mengajar di Perguruan Tinggi dalam Rangka Pengembangan SDM. Jakarta: Rineka Cipta.

Wahab, Abdi A. 2003. Belajar Mengajar di Perguruan Tinggi. Bandung: Rosdakarya.

Wahyuningrum dalam Simamora. 2004. Manajemen Sumber Daya Manusia. Yogyakarta: Sekolah Tinggi Ilmu Ekonomi YKPN.

Xu, Yong Ping. 2008. Student-Centered Learning of IC Design in a Project-based Undergraduate Course. Singapore: National University of Singapore Press. 